\title{
Investigation of environmental noise level status in Oshodi/ Isolo local government of Lagos State, Nigeria
}

Salami L 1, ${ }^{*}$, Akinbomi JG ${ }^{2}$, Kayode VM 2, Shipe DF 2, Adebanjo IT 2, Ayoade RA ${ }^{2}$, Ohiomoba OD 2, Ibrahim IA ${ }^{2}$ and Ajikanle MA ${ }^{2}$

\author{
${ }^{1}$ Environmental Engineering Research Unit, Department of Chemical Engineering, Lagos State University, Epe, Lagos \\ State, Nigeria. \\ ${ }^{2}$ Department of Chemical Engineering, Lagos State University, Epe, Lagos State, Nigeria.
}

Global Journal of Engineering and Technology Advances, 2022, 10(01), 107-116

Publication history: Received on 09 December 2021; revised on 22 January 2022; accepted on 24 January 2022

Article DOI: https://doi.org/10.30574/gjeta.2022.10.1.0021

\begin{abstract}
Noise is a public nuisance which can result to adverse health effects. This work was carried out to investigate the environmental noise level status in Oshodi/Isolo Local Government of Lagos State, Nigeria. 10 different locations were selected in each of educational, industrial, traffic, commercial and residential areas which were coded EA - EJ, IA - IJ, TA - TJ, CA - CJ and RA - RJ respectively. All the chosen locations were coordinated using handheld Global Positioning System (GPS) for the purpose of universal identification. Noise level were measured in each of the selected locations using sound level meter (SLM) in the morning (7 - 9 a.m), afternoon (12 - 2 p.m) and evening ( $4-6$ p.m). The results revealed that the noise level in educational areas ranged between 67.90 and $79.90 \mathrm{~dB}$, between 50.70 and $72.30 \mathrm{~dB}$ and between 51.70 and $72.30 \mathrm{~dB}$ for morning, afternoon and evening respectively while the industrial areas varied between 70.20 and $77.40 \mathrm{~dB}$, between 70.30 and $72.90 \mathrm{~dB}$ and between 70.20 and $76.40 \mathrm{~dB}$ for morning, afternoon and evening respectively. The noise level in traffic areas ranged between 70.80 and $90.30 \mathrm{~dB}$, between 70.70 and $79.70 \mathrm{~dB}$ and between 67.50 and $77.90 \mathrm{~dB}$ for morning, afternoon and evening respectively while the commercial areas varied between 68.50 and $88.80 \mathrm{~dB}$, between 73.20 and $78.90 \mathrm{~dB}$ and between 70.80 and $78.30 \mathrm{~dB}$ for morning, afternoon and evening respectively. The noise level for residential areas ranged between 68.77 and $77.20 \mathrm{~dB}$, between 69.70 and 71.60 $\mathrm{dB}$ and between 68.20 and $72.20 \mathrm{~dB}$ for morning, afternoon and evening respectively. The threshold limits by National Environmental Standards and Regulations Enforcement Agency (NESREA) for noise level in educational, residential, commercial, industrial and traffic areas are 45, 50, 55, 70 and $80 \mathrm{~dB}$ respectively while Lagos State Environmental Protection Agency (LASEPA) threshold limits are 55, 70 and $90 \mathrm{~dB}$ for residential, commercial and industrial areas respectively. These indicated that the noise level in the investigated areas exceeded the NESREA and LASEPA standard limits for noise level. The analysis of variance (ANOVA) showed that at 5 percent significant level, there was no statistical difference in the mean noise level in all the investigated areas. It was concluded that Oshodi/Isolo Local Government of Lagos State was polluted and the relevant authorities need to be proactive and take urgent steps to minimize the level of noise pollution in Oshodi/Isolo Local Government of Lagos State.
\end{abstract}

Keywords: Health effects; Investigation; Noise level; Oshodi/Isolo; Status

\section{Introduction}

Noise pollution can be defined as unpleasant and unwanted excessive sound beyond a certain limits in a particular area which is disagreeable and undesired to the recipient [1]. It is also the generation of sounds which are irritating, having a high pitch when compared to the humans hearing capabilities. The sources of noise pollution include industrial, transportation, public address systems, agricultural machines, military equipment, household and religious activities [2

\footnotetext{
* Corresponding author: Salami L; Email: SalamiLukumon@yahoo.com

Environmental Engineering Research Unit, Department of Chemical Engineering, Lagos State University, Epe, Lagos State, Nigeria. 
- 4]. Noise pollution causes a lot of adverse effects to human life. These include hearing impairment, interference with spoken communication, disturbances in mental health and cardiovascular disturbances [1, 5 - 8].

Several scholars have worked on noise pollution [1, 4 - 5, 7, 9 - 16]. Akintuji et al., (2014) [9] examined the distribution of noise in Bariga area of Lagos State through monitoring and GIS based mapping. The examination revealed a high index of above $55 \mathrm{~dB}(\mathrm{~A})$ in the area which was above the World Health Organisation (WHO) standard for comfortability and low annoyance response to noise. Oluwaseun et al., (2015) [13] studied the road traffic environmental noise and impacts on resident of IKEJA Local Government area of Lagos State, Nigeria. The study showed that car noise affected the residents the most, followed by noise from motor cycles and lorries. Usikalu and Kolawole (2018) [11] assessed the noise pollution in selected locations in Ota, Ogun State, NigeriaS. The assessment indicated that there were increased noise pollution in Oju - Ore and Toll gate as a result of high numbers of vehicular movement and road congestion in the study area.

Adjobi and Akingbemisola 2019 [12] carried out a comparative analysis of noise pollution level I selected areas of Lagos state. The analysis revealed that the noise level in the selected areas considered exceeded the regulatory standards which resulted in unpleasant and uncomfortable life style for the urban dwellers. Christopher and Adeniyi (2020) [16] investigated the traffic noise pollution in residential neighbourhood of Alimosho Local Government of Lagos State, Nigeria. The investigation showed that the mean traffic noise in the area was $71.70 \mathrm{~dB}(\mathrm{~A})$ which was above the recommended standard of $55 \mathrm{~dB}(\mathrm{~A})$ by LASEPA. It is obvious from the available literature that works on noise pollution status of Oshodi/Isolo Local Government of Lagos State are very scarce in the literature. Therefore the aim of this work is to investigate the environmental noise level status of Oshodi/Isolo Local Government of Lagos State, Nigeria with a view to establishing the ANOVA for the areas under investigation.

It is imperative that the noise level in Oshodi/Isolo Local Governmnent of Lagos State is investigated in order to make available fundamental noise pollution data which can be used by environmental engineers, scientists, chemical engineers and other users of such materials who might want to work on noise pollution which justifies this work. This work also serves as a tool for policy makers and local authorities for decision msking in order to sanitise our environment and improve the quality of life of the people especially in Oshodi/Isolo Local Government of Lagos State, Nigeria which further justifies this work.

\section{Methodology}

\subsection{The Study Area}

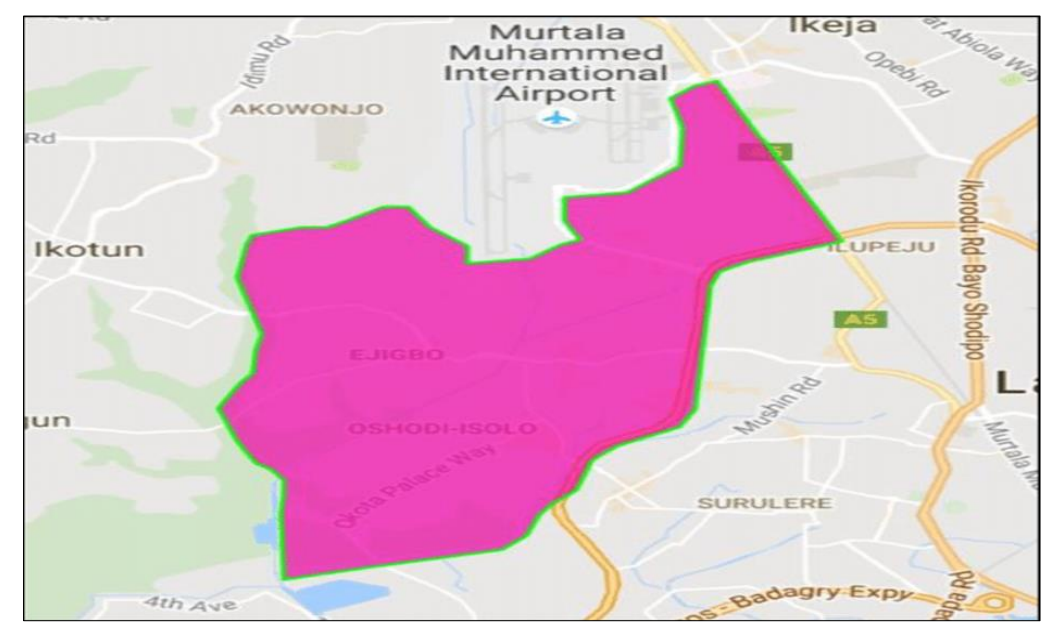

Figure 1 A typical google map of Oshodi/Isolo Local Government of Lagos State; (Source: City population, 2016 [21])

Oshodi/Isolo Local Government is one of the twenty Local Government in Lagos State, South - west geopolitical zone of Nigeria. It was carved out of Mushin Local Government in 1982 [17]. Oshodi/Isolo is on longititude 6 33' 38" N and latitude $3^{\circ} 20^{\prime} 7^{\prime \prime} \mathrm{E}$, having altitude of $55 \mathrm{~m}$ [18]. It has land mass of $41.98 \mathrm{~km}^{2}$ and a total population of 1,134,548 with population density of $27,025.92$ [19]. The average temperature of the area is $27^{\circ} \mathrm{C}$, the average wind speed and humidity of the area were estimated at $10 \mathrm{~km} / \mathrm{h}$ and 63 percent respectively [20]. It has rainy and dry seasons as two distinct seasons and is a hub for trade, hosting several markets such as Aswani, Mosafejo and Owonifari market [20]. It houses 
Isolo industrial estate, Lagos State Development and Property Corporation (LSDPC) and Jakande residential estate [19] with several banks, religious centers and hotels. A typical google map of Oshodi/Isolo Local Government is shown in Figure 1.

\subsection{Measurement Locations}

Different areas which include educational, industrial, traffic, commercial and residential were chosen for investigation. In each area, 10 various locations where noise level were perceived to be high by observation were selected as measurement locations. The selected locations were labeled EA - EJ, IA - IJ, TA - TJ, CA - CJ and RA - RJ for educational, industrial, traffic, commercial and residential areas respectively. All the selected locations were coordinated using handheld Global Positioning System (GPS) (Etrex 12 Garmin model) for the purpose of universal identification.

\subsection{Measurement of Noise Level}

In each of the selected locations, noise levels were recorded for 60 seconds using sound level meter (SLM) (2310 SL model) which was held in a way that the microphone was $1 \mathrm{~m}$ from reflecting surface. The maximum value of noise in each of the selected locations was chosen as the measured noise level. This procedure was carried out in the morning (7 - 9 a.m), afternoon (12 - 2 p.m) and evening (4-6 p.m) in the month of November, 2021.

\section{Results and discussion}

The specifications for the selected locations for educational, industrial, traffic, commercial and residential areas are shown in Tables 1 - 5 respectively.

Table 1 Specifications for the measurement of educational areas locations

\begin{tabular}{|c|c|c|c|c|c|}
\hline \multirow{2}{*}{ S/N } & \multicolumn{2}{|c|}{ Coordinates } & Elevation (m) & Locations & $\begin{array}{c}\text { Identification } \\
\text { code }\end{array}$ \\
\cline { 2 - 5 } & Northing & Easting & & Ewela road & EA \\
\hline 1 & $06^{0} 33.189^{\prime}$ & $003^{0} 20.651^{\prime}$ & 32.92 & Iyana Isolo & EB \\
\hline 2 & $06^{0} 31.868^{\prime}$ & $003^{0} 20.029^{\prime}$ & 33.83 & Isolo estate & EC \\
\hline 3 & $06^{0} 31.829^{\prime}$ & $003^{0} 19.879^{\prime}$ & 28.35 & Ile Ewe meta & ED \\
\hline 4 & $06^{0} 31.831^{\prime}$ & $003^{0} 19.820^{\prime}$ & 29.26 & Ishaga & EE \\
\hline 5 & $06^{0} 31.662^{\prime}$ & $003^{0} 19.540^{\prime}$ & 29.26 & EF \\
\hline 6 & $06^{0} 31.218^{\prime}$ & $003^{0} 19.279^{\prime}$ & 21.03 & Ire - Akari estate & EG \\
\hline 7 & $06^{0} 31.139^{\prime}$ & $003^{0} 19.257^{\prime}$ & 28.35 & EH road & EI \\
\hline 8 & $06^{0} 33.125^{\prime}$ & $003^{0} 19.296^{\prime}$ & 16.15 & Okota school complex & EJ \\
\hline 9 & $06^{0} 33.033^{\prime}$ & $003^{0} 19.328^{\prime}$ & 16.76 & Okota school complex & \\
\hline 10 & $06^{0} 33.099^{\prime}$ & $003^{0} 19.314^{\prime}$ & 12.80 & & \\
\hline
\end{tabular}

Table 2 Specifications for the measurement of industrial areas locations

\begin{tabular}{|c|c|c|c|c|c|}
\hline \multirow{2}{*}{ S/N } & \multicolumn{2}{|c|}{ Coordinates } & Elevation (m) & Locations & $\begin{array}{c}\text { Identification } \\
\text { code }\end{array}$ \\
\cline { 2 - 5 } & Northing & Easting & & & Aswani road \\
\hline 1 & $06^{0} 32.406^{\prime}$ & $003^{0} 20.088^{\prime}$ & 28.35 & IA \\
\hline 2 & $06^{0} 32.413^{\prime}$ & $003^{0} 20.030^{\prime}$ & 16.46 & Aswani road & IB \\
\hline 3 & $06^{0} 32.456^{\prime}$ & $003^{0} 20.037^{\prime}$ & 19.51 & Market road & IC \\
\hline 4 & $06^{0} 32.507^{\prime}$ & $003^{0} 20.045^{\prime}$ & 15.54 & Ajao road & ID \\
\hline
\end{tabular}




\begin{tabular}{|c|c|c|c|c|c|}
\hline 5 & $06^{0} 32.509^{\prime}$ & $003^{0} 20.021^{\prime}$ & 8.84 & Ajao road & IE \\
\hline 6 & $06^{0} 31.620^{\prime}$ & $003^{0} 19.815^{\prime}$ & 18.29 & Ilasa road & IF \\
\hline 7 & $06^{0} 31.611^{\prime}$ & $003^{0} 19.835^{\prime}$ & 21.34 & Cowbell way & IG \\
\hline 8 & $06^{0} 31.605^{\prime}$ & $003^{0} 19.847^{\prime}$ & 24.69 & Cowbell way & IH \\
\hline 9 & $06^{0} 31.600^{\prime}$ & $003^{0} 19.948^{\prime}$ & 28.04 & Cowbell way & II \\
\hline 10 & $06^{0} 31.558^{\prime}$ & $003^{0} 19.807^{\prime}$ & 21.34 & Ilasa road & IJ \\
\hline
\end{tabular}

Table 3 Specifications for the measurement of traffic areas locations

\begin{tabular}{|c|c|c|c|c|c|}
\hline \multirow{2}{*}{ S/N } & \multicolumn{2}{|c|}{ Coordinates } & \multirow{2}{*}{ Elevation (m) } & Locations & $\begin{array}{l}\text { Identification } \\
\text { code }\end{array}$ \\
\cline { 2 - 5 } & Northing & Easting & & Oshodi Isale & TA \\
\hline 1 & $06^{0} 33.396^{\prime}$ & $003^{0} 21.070^{\prime}$ & 25.91 & Araromi junction & TB \\
\hline 2 & $06^{0} 33.454^{\prime}$ & $003^{0} 21.051^{\prime}$ & 25.91 & Brown street & TC \\
\hline 3 & $06^{0} 33.521^{\prime}$ & $003^{0} 21.020^{\prime}$ & 25.60 & Bolade station & TD \\
\hline 4 & $06^{0} 33.014^{\prime}$ & $003^{0} 20.998^{\prime}$ & 42.67 & Anyibi street & TE \\
\hline 5 & $06^{0} 33.667^{\prime}$ & $003^{0} 20.967^{\prime}$ & 27.43 & Akinniku street & TF \\
\hline 6 & $06^{0} 33.714^{\prime}$ & $003^{0} 20.943^{\prime}$ & 32.61 & Arena junction & TH \\
\hline 7 & $06^{0} 33.817^{\prime}$ & $003^{0} 20.983^{\prime}$ & 27.43 & Igbeyiadun street & TI \\
\hline 8 & $06^{0} 33.817^{\prime}$ & $003^{0} 20.900^{\prime}$ & 28.04 & Local government road & TJ \\
\hline 10 & $06^{0} 33.761^{\prime}$ & $003^{0} 20.708^{\prime}$ & 28.65 & Adeyemi street & \\
\hline
\end{tabular}

Table 4 Specifications for the measurement of commercial areas locations

\begin{tabular}{|c|c|c|c|c|c|}
\hline \multirow{2}{*}{ S/N } & \multicolumn{2}{|c|}{ Coordinates } & Elevation (m) & Locations & $\begin{array}{c}\text { Identification } \\
\text { code }\end{array}$ \\
\cline { 2 - 5 } & Northing & Easting & & Suwebaju & CA \\
\hline 1 & $06^{0} 33.350^{\prime}$ & $003^{0} 20.933^{\prime}$ & 27.13 & Resettlement market & CB \\
\hline 2 & $06^{0} 33.383^{\prime}$ & $003^{0} 20.933^{\prime}$ & 24.38 & Modern market & CC \\
\hline 3 & $06^{0} 33.040^{\prime}$ & $003^{0} 20.983^{\prime}$ & 24.38 & Post office road & CD \\
\hline 4 & $06^{0} 33.385^{\prime}$ & $003^{0} 20.907^{\prime}$ & 31.70 & Araromi & CE \\
\hline 5 & $06^{0} 33.442^{\prime}$ & $003^{0} 20.986^{\prime}$ & 25.00 & Ogunlani street & CF \\
\hline 6 & $06^{0} 33.522^{\prime}$ & $003^{0} 20.925^{\prime}$ & 27.13 & Marcony lane & CG \\
\hline 7 & $06^{0} 33.515^{\prime}$ & $003^{0} 21.018^{\prime}$ & 32.92 & Market complex & CH \\
\hline 8 & $06^{0} 33.543^{\prime}$ & $003^{0} 21.008^{\prime}$ & 35.05 & Adekoya street & CI \\
\hline 9 & $06^{0} 33.591^{\prime}$ & $003^{0} 20.988^{\prime}$ & 32.61 & Ariyibi oke & CJ \\
\hline 10 & $06^{0} 33.658^{\prime}$ & $003^{0} 20.931^{\prime}$ & 31.09 & & \\
\hline
\end{tabular}


Table 5 Specifications for the measurement of residential areas locations

\begin{tabular}{|c|c|c|c|c|c|}
\hline \multirow{2}{*}{ S/N } & \multicolumn{2}{|c|}{ Coordinates } & \multirow{2}{*}{ Elevation (m) } & Locations & $\begin{array}{c}\text { Identification } \\
\text { code }\end{array}$ \\
\cline { 2 - 5 } & Northing & Easting & & & Abiodun seriki close \\
\hline 1 & $06^{0} 33.664^{\prime}$ & $003^{0} 20.953^{\prime}$ & 29.57 & Recreation road & RB \\
\hline 2 & $06^{0} 31.976^{\prime}$ & $003^{0} 19.880^{\prime}$ & 40.84 & Alade street & RC \\
\hline 3 & $06^{0} 32.040^{\prime}$ & $003^{0} 19.820^{\prime}$ & 30.18 & Olumuyiwa street & RD \\
\hline 4 & $06^{0} 32.151^{\prime}$ & $003^{0} 19.821^{\prime}$ & 26.82 & Adebisi street & RE \\
\hline 5 & $06^{0} 32.247^{\prime}$ & $003^{0} 19.821^{\prime}$ & 25.00 & Bola street & RF \\
\hline 6 & $06^{0} 32.250^{\prime}$ & $003^{0} 19.667^{\prime}$ & 18.29 & Transformer way & RG \\
\hline 7 & $06^{0} 32.267^{\prime}$ & $003^{0} 19.650^{\prime}$ & 9.14 & Ajiriabo street & RH \\
\hline 8 & $06^{0} 32.167^{\prime}$ & $003^{0} 19.617^{\prime}$ & 18.29 & Shodeinde street & RI \\
\hline 9 & $06^{0} 32.133^{\prime}$ & $003^{0} 19.600^{\prime}$ & 18.29 & Aderinto street & RJ \\
\hline 10 & $06^{0} 32.005^{\prime}$ & $003^{0} 19.617^{\prime}$ & 15.85 & & \\
\hline
\end{tabular}

The numerical values of noise level for educational and industrial areas are presented in Table 6. In educational areas considered in this work, the noise level ranged between 67.90 and $79.90 \mathrm{~dB}$, between 50.70 and $72.30 \mathrm{~dB}$ and between 51.70 and $72.30 \mathrm{~dB}$ for morning, afternoon and evening respectively. NESREA standard limit for noise level in education areas is $45 \mathrm{~dB}$ [22]. This revealed that the noise level in the educational areas considered in this work were higher than the standard limits stipulated by NESREA which indicated that the areas were polluted. The work of Usikalu and Kolawole (2018) [11] also indicated that noise level in covenant university was higher than the NESREA standard. This revealed that the authorities in educational institute need to find a way of minimizing the noise level.

Table 6 Numerical values of noise level in educational and industrial areas

\begin{tabular}{|c|c|c|c|c|c|c|c|c|}
\hline \multirow{2}{*}{ S/N } & \multicolumn{5}{|c|}{ Educational } & \multicolumn{4}{c|}{ Industrial } \\
\cline { 2 - 9 } & Code & $\begin{array}{c}\text { Morning } \\
(\mathrm{dB})\end{array}$ & $\begin{array}{c}\text { Afternoon } \\
(\mathrm{dB})\end{array}$ & $\begin{array}{c}\text { Evening } \\
(\mathrm{dB})\end{array}$ & Code & $\begin{array}{c}\text { Morning } \\
(\mathrm{dB})\end{array}$ & $\begin{array}{c}\text { Afternoon } \\
(\mathrm{dB})\end{array}$ & $\begin{array}{c}\text { Evening } \\
(\mathrm{dB})\end{array}$ \\
\hline 1 & EA & 79.70 & 72.30 & 72.30 & IA & 71.00 & 70.60 & 70.80 \\
\hline 2 & EB & 79.90 & 67.80 & 69.20 & IB & 74.80 & 71.60 & 70.90 \\
\hline 3 & EC & 78.60 & 63.30 & 69.10 & IC & 70.60 & 70.50 & 71.10 \\
\hline 4 & ED & 79.20 & 63.40 & 67.10 & ID & 77.40 & 72.90 & 73.20 \\
\hline 5 & EE & 79.60 & 63.90 & 64.00 & IE & 70.90 & 70.30 & 71.20 \\
\hline 6 & EF & 67.90 & 62.90 & 62.60 & IF & 70.80 & 70.40 & 70.20 \\
\hline 7 & EG & 77.70 & 67.00 & 65.80 & IG & 70.20 & 70.60 & 72.10 \\
\hline 8 & EH & 70.60 & 50.70 & 55.30 & IH & 70.70 & 70.60 & 72.50 \\
\hline 9 & EI & 70.60 & 55.80 & 55.00 & II & 77.60 & 72.70 & 76.40 \\
\hline 10 & EJ & 76.80 & 56.00 & 51.70 & IJ & 70.80 & 70.70 & 71.00 \\
\hline
\end{tabular}

The noise level in industrial areas investigated varied between 70.20 and $77.40 \mathrm{~dB}$, between 70.30 and $72.90 \mathrm{~dB}$ and between 70.20 and $76.40 \mathrm{~dB}$ for morning, afternoon and evening respectively. The NESREA and LASEPA noise threshold limits for industrial areas are 70 and $90 \mathrm{~dB}$ respectively [22 - 23]. The noise level in all the areas investigated were below the LASEPA standard however majority of the areas were slightly above the NESREA standard. It can be deduced 
that the industries in the investigated areas were making concerted efforts to control the noise from their industrial activities.

The numerical values of noise level in traffic and commercial areas of Oshodi/Isolo Local Government of Lagos State are shown in Table 7. In the traffic areas, the noise level ranged between 70.80 and $90.30 \mathrm{~dB}$, between 70.70 and $79.90 \mathrm{~dB}$ and between 67.50 and $77.90 \mathrm{~dB}$ for morning, afternoon and evening respectively. The NESREA threshold limit for noise level in traffic areas is $80 \mathrm{~dB}$. This showed the investigated areas were not polluted in the afternoon and evening however locations TB, TC, TE, TF and TH were polluted in the morning. This can be attributed to large volume of traffic normally witnessed in the morning in Lagos State especially in the studied area. This points to the fact that the regulatory body needs to be effective and efficient on their work with a view to controlling the noise level in the studied area especially in the morning.

Table 7 Numerical values of noise level in traffic and commercial areas

\begin{tabular}{|c|c|c|c|c|c|c|c|c|}
\hline \multirow{2}{*}{ S/N } & \multicolumn{4}{|c|}{ Traffic } & \multicolumn{4}{c|}{ Commercial } \\
\cline { 2 - 9 } & Code & $\begin{array}{c}\text { Morning } \\
\text { (dB) }\end{array}$ & $\begin{array}{c}\text { Afternoon } \\
\text { (dB) }\end{array}$ & $\begin{array}{c}\text { Evening } \\
\text { (dB) }\end{array}$ & Code & $\begin{array}{c}\text { Morning } \\
\text { (dB) }\end{array}$ & $\begin{array}{c}\text { Afternoon } \\
\text { (dB) }\end{array}$ & $\begin{array}{c}\text { Evening } \\
\text { (dB) }\end{array}$ \\
\hline 1 & TA & 80.00 & 70.80 & 73.80 & CA & 79.80 & 78.20 & 78.30 \\
\hline 2 & TB & 90.30 & 71.00 & 74.70 & CB & 88.80 & 76.10 & 71.80 \\
\hline 3 & TC & 86.40 & 71.10 & 77.20 & CC & 68.80 & 73.20 & 78.00 \\
\hline 4 & TD & 80.30 & 77.20 & 72.00 & CD & 78.50 & 83.70 & 73.00 \\
\hline 5 & TE & 81.30 & 70.80 & 77.20 & CE & 79.50 & 76.90 & 76.20 \\
\hline 6 & TF & 86.90 & 70.70 & 77.70 & CF & 75.80 & 84.10 & 71.70 \\
\hline 7 & TG & 76.40 & 78.30 & 77.90 & CG & 80.50 & 78.90 & 78.50 \\
\hline 8 & TH & 81.40 & 79.70 & 72.40 & CH & 71.80 & 73.80 & 71.60 \\
\hline 9 & TI & 79.30 & 71.20 & 77.30 & CI & 77.20 & 75.30 & 70.80 \\
\hline 10 & TJ & 70.80 & 70.80 & 67.50 & CJ & 84.90 & 74.10 & 71.00 \\
\hline
\end{tabular}

The noise level in the commercial areas investigated varied between 68.80 and $88.80 \mathrm{~dB}$, between 73.20 and $78.90 \mathrm{~dB}$ and between 70.80 and $78.30 \mathrm{~dB}$ for morning, afternoon and evening respectively. The NESREA and LASEPA standard limits for noise level in commercial areas are 55 and $70 \mathrm{~dB}$ respectively. This depicted that the areas investigated were polluted throughout the day except location CC which can be considered not to be polluted in the morning. The work of Akintuyi et al., (2014) [9] also revealed that the commercial areas of Bariga, Lagos State were also polluted. The study of Adejobi and Akingbemisola (2019) [12] pointed out that the commercial areas of Ikeja of Lagos State were polluted. This is worrisome and urgent actions need to be taken especially by the regulatory agencies to minimize the noise level in commercial areas of Lagos State.

The numerical values of noise level in residential areas of Oshodi/Isolo Local Government of Lagos State and noise level threshold limits by NESREA and LASEPA are presented in Table 8. The noise level in the residential areas ranged between 68 and $77.20 \mathrm{~dB}$, between 69.70 and $71.60 \mathrm{~dB}$ and between 68.20 and $72.20 \mathrm{~dB}$ for morning, afternoon and evening respectively. The standard limits for noise level in residential areas are 50 and $55 \mathrm{~dB}$ for NESREA and LASEPA respectively. The noise level in all the examined residential areas were above the NESREA and LASEPA threshold limits which clearly indicated that all the examined residential areas were polluted. This may be attributed to the proximity of the residential areas to the major roads.

ANOVA was carried out on the generated noise level data shown in Tables 6 - 8 using the in - built Microsoft excel version 2007. The one way ANOVA for educational, industrial, traffic, commercial and residential areas of Oshodi/Isolo Local Government of Lagos State are depicted in Tables 9 - 13 respectively. ANOVA determines if there exists a statistical significant difference among the means of three or more groups. The significant level used for ANOVA in this work was 0.05. The significant level is the probability of not accepting the null hypothesis when it is true. 
Table 8 Numerical values of noise level in residential areas and noise standards

\begin{tabular}{|c|c|c|c|c|c|c|c|}
\hline \multirow[t]{2}{*}{$\mathbf{S} / \mathbf{N}$} & \multicolumn{4}{|c|}{ Residential } & \multicolumn{3}{|c|}{ Standards } \\
\hline & Code & $\begin{array}{l}\text { Morning } \\
\text { (dB) }\end{array}$ & $\begin{array}{l}\text { Afternoon } \\
\qquad(\mathrm{dB})\end{array}$ & $\begin{array}{c}\text { Evening } \\
\text { (dB) }\end{array}$ & Areas & $\begin{array}{c}{ }^{* *} \text { NESREA } \\
\text { (dB) }\end{array}$ & $\begin{array}{c}* * * \text { LASEPA } \\
\text { (dB) }\end{array}$ \\
\hline 1 & RA & 77.20 & 71.60 & 72.20 & \multirow[t]{2}{*}{ Educational } & \multirow[t]{2}{*}{45} & \multirow[t]{2}{*}{-} \\
\hline 2 & $\mathrm{RB}$ & 76.30 & 70.70 & 68.70 & & & \\
\hline 3 & $\mathrm{RC}$ & 71.30 & 70.70 & 70.50 & \multirow[t]{2}{*}{ Residential } & \multirow[t]{2}{*}{50} & \multirow[t]{2}{*}{ - } \\
\hline 4 & $\mathrm{RD}$ & 71.00 & 70.10 & 70.00 & & & \\
\hline 5 & $\mathrm{RE}$ & 68.00 & 68.00 & 70.30 & \multirow[t]{2}{*}{ Commercial } & \multirow[t]{2}{*}{55} & \multirow[t]{2}{*}{70} \\
\hline 6 & $\mathrm{RF}$ & 70.50 & 69.70 & 70.20 & & & \\
\hline 7 & $\mathrm{RG}$ & 70.80 & 69.70 & 70.30 & \multirow[t]{2}{*}{ Industrial } & \multirow[t]{2}{*}{70} & \multirow[t]{2}{*}{90} \\
\hline 8 & RH & 71.60 & 71.30 & 68.20 & & & \\
\hline 9 & RI & 73.40 & 70.70 & 68.40 & \multirow[t]{2}{*}{ Traffic } & \multirow[t]{2}{*}{80} & \multirow[t]{2}{*}{-} \\
\hline 10 & RJ & 74.00 & 71.00 & 71.30 & & & \\
\hline
\end{tabular}

Table 9 One way ANOVA for noise level in educational areas

\begin{tabular}{|l|c|c|c|c|c|}
\hline Sources of variation & $\begin{array}{c}\text { Sum of square } \\
\text { (SS) }\end{array}$ & $\begin{array}{c}\text { Degree of freedom } \\
\text { (df) }\end{array}$ & $\begin{array}{c}\text { Mean square } \\
\text { (MS) }\end{array}$ & F value & F critical \\
\hline Between treatment & 126.31 & 2 & 63.16 & 1.71 & 3.35 \\
\hline Residual & 998 & 27 & 36.96 & & \\
\hline Total & $1,124,31$ & 29 & & & \\
\hline
\end{tabular}

Table 10 One way ANOVA for noise level in industrial areas

\begin{tabular}{|c|c|c|c|c|c|}
\hline $\begin{array}{c}\text { Sources of } \\
\text { variation }\end{array}$ & $\begin{array}{c}\text { Sum of square } \\
\text { (SS) }\end{array}$ & $\begin{array}{c}\text { Degree of freedom } \\
\text { (df) }\end{array}$ & $\begin{array}{c}\text { Mean } \\
\text { square (MS) }\end{array}$ & F value & F critical \\
\hline Between treatment & 1.53 & 2 & 0.76 & 0.18 & 3.35 \\
\hline Residual & 115.85 & 27 & 4.29 & & \\
\hline Total & 117.38 & 29 & & & \\
\hline
\end{tabular}

Table 11 One way ANOVA for noise level in traffic areas

\begin{tabular}{|c|c|c|c|c|c|}
\hline $\begin{array}{c}\text { Sources of } \\
\text { variation }\end{array}$ & $\begin{array}{c}\text { Sum of square } \\
\text { (SS) }\end{array}$ & $\begin{array}{c}\text { Degree of freedom } \\
\text { (df) }\end{array}$ & $\begin{array}{c}\text { Mean square } \\
\text { (MS) }\end{array}$ & F value & F critical \\
\hline Between treatment & 45.15 & 2 & 22.57 & 1.21 & 3.35 \\
\hline Residual & 504.03 & 27 & 18.67 & & \\
\hline Total & 549.18 & 29 & & & \\
\hline
\end{tabular}


Table 12 One way ANOVA for noise level in commercial areas

\begin{tabular}{|c|c|c|c|c|c|}
\hline $\begin{array}{c}\text { Sources of } \\
\text { variation }\end{array}$ & $\begin{array}{c}\text { Sum of square } \\
\text { (SS) }\end{array}$ & $\begin{array}{c}\text { Degree of freedom } \\
\text { (df) }\end{array}$ & $\begin{array}{c}\text { Mean square } \\
\text { (MS) }\end{array}$ & F value & F critical \\
\hline Between treatment & 4.57 & 2 & 2.28 & 0.12 & 3.35 \\
\hline Residual & 532.59 & 27 & 19.73 & & \\
\hline Total & 537.16 & 29 & & & \\
\hline
\end{tabular}

Table 13 One way ANOVA for noise level in residential areas

\begin{tabular}{|l|c|c|c|c|c|}
\hline Sources of variation & $\begin{array}{c}\text { Sum of } \\
\text { square (SS) }\end{array}$ & $\begin{array}{c}\text { Degree of } \\
\text { freedom (df) }\end{array}$ & $\begin{array}{c}\text { Mean square } \\
\text { (MS) }\end{array}$ & F value & $\begin{array}{c}\text { F } \\
\text { critical }\end{array}$ \\
\hline Between treatment & 2.87 & 2 & 1.43 & 0.41 & 3.35 \\
\hline Residual & 95.32 & 27 & 3.53 & & \\
\hline Total & 98.19 & 29 & & & \\
\hline
\end{tabular}

The null hypothesis used was that the mean noise level for morning, afternoon and evening were equal while the alternative hypothesis was that the mean noise level were not equal for morning, afternoon and evening in educational areas. The same applied for industrial, traffic, commercial and residential areas. In Tables $9-13$, the F values were less than the F critical values in each area. This means that the null hypothesis cannot be rejected which indicated that at 5 percent significant level, there was no statistical difference in mean noise level for educational industrial, traffic, commercial and residential area. The 5 percent significant level implied that there was a risk of 5 percent for taking the mean noise level not to be different in all the areas.

\section{Conclusion}

The environmental noise level status in Oshodi/Isolo Local Government of Lagos state, Nigeria has been investigated. The noise level in the educational areas varied between 67.90 and $79.90 \mathrm{~dB}$, between 50.70 and $72.30 \mathrm{db}$ and between 51.70 and $72.30 \mathrm{~dB}$ for morning, afternoon and evening respectively while the noise level threshold by NESREA is $45 \mathrm{~dB}$. The noise level in industrial areas ranged between 70.20 and $77.40 \mathrm{~dB}$, between 70.30 and $72.90 \mathrm{~dB}$ and between 70.20 and $76.40 \mathrm{db}$ for morning, afternoon and evening respectively while the NESREA and LASEPA standard limits for noise in industrial areas are 70 and $90 \mathrm{~dB}$ respectively. The noise level in the traffic areas varied between 70.80 and $90.30 \mathrm{~dB}$, between 70.70 and $79.70 \mathrm{~dB}$ and between 67.50 and $77.90 \mathrm{~dB}$ for morning, afternoon and evening respectively while the NESREA threshold limit is $80 \mathrm{~dB}$. For commercial areas, the noise level ranged between 68.80 and $88.80 \mathrm{~dB}$, between 73.20 and $78.90 \mathrm{~dB}$ and between 70.80 and $78.30 \mathrm{~dB}$ for morning, afternoon and evening respectively but the NEASREA and LASEPA noise standard limits are 55 and $70 \mathrm{~dB}$ respectively. The noise level in residential areas varied between 68 and $77.20 \mathrm{~dB}$, between 69.70 and $71.60 \mathrm{~dB}$ and between 68.20 and $72.20 \mathrm{~dB}$ for morning, afternoon and evening respectively. These noise level were above the NESREA and LASEPA threshold limits of 50 and $55 \mathrm{~dB}$ respectively for residential areas. The ANOVA results revealed that at 5 percent significant, there was no statistical difference in the mean noise level for educational, industrial, traffic, commercial and residential area. It was concluded that Oshodi/Isolo Local Government of Lagos State was polluted in term of noise hence the authorities need to be proactive and take urgent actions to minimize the level of noise pollution inOshodi/Isolo Local Government of Lagos state.

\section{Recommendations}

The following are recommended in order to ensure reduction in noise pollution level of the investigated areas.

- $\quad$ Trees should be planted all around as this reduces noise level in the study area.

- $\quad$ People should try as much as possible to use public transport as this will reduce the volume of traffic hence the noise level.

- In schools, students should be engaged as much as possible as this will minimize generation of noise. 
- Noise impact assessment should be carried out for any additional or new project in the area before granting approval for such as project.

- The regulatory agencies should enforce all relevant legislative laws with a view of minimizing noise pollution

- People should be educated on the effects of noise pollution and why it should be curbed.

- People should cultivate the habit of keeping moderately the volume of electronic devices.

- All the bad roads should be repaired to easy the flow of traffic.

\section{Compliance with ethical standards}

\section{Acknowledgments}

The authors appreciate the understanding and efforts of the residence of Oshodi/Isolo Local Government area of Lagos State, towards the success of this work.

\section{Disclosure of conflict of interest}

Authors have declared that no competing interests exist.

\section{References}

[1] Madhu B, Deepak V. Investigation and examination of noise pollution - definition, sources effect, monitoring and control. International Journal of Research in Social Sciences. 2020; 10(7): 182 - 206.

[2] Conserve Energy Future. What is noise pollution. Accessed date: November 23, 2021.

[3] Schomer P. Assessment of noise annoyance. A white paper by Schomer and Associates International. 2001; 39.

[4] Berglund B, Lindvall T. Community noise. Archives of the centre for Sensory Research. 1995; 2(1): 1 - 95.

[5] Singh N, Davar S. Noise pollution - sources, effects and control. Journal of Human Ecology. 2004; 16(3): 181 187.

[6] Senzaki M, Kadoya T, Francis CD. Direct and indirect effects of noise pollution aiter biological communities in and near noise - exposed environments. Proceedings of Royal Society. 2020; 287: 20200176.

[7] Hsu T, Ryherd E, Wage K, Ackerman J. Noise pollution in hospitals: Impact to patients and clinic review. Journal of Community Medicine. 2012; 19(7): 1 - 7.

[8] Goines L, Hagler L. Noise pollution: A modern plague. Southern Medical Journal. 2007; 100 (3): 287 - 294.

[9] Akintuyi AO, Raji SA, Adewun D, Wunude EO. GIS based assessment and mapping of noise pollution in Bariga area of Lagos State, Nigeria. Sokoto Journal of Social Sciences. 2014; 4 (1): 154 - 167.

[10] Oyedepo SO. Effective noise control measures and sustainable development in Nigeria. World Journal of Environmental Engineering. 2013; 1(1): 5 - 15.

[11] Usikalu MR, Kolawole O. Assessment of noise pollution in selected locations in Ota, Nigeria. International Journal of Mechanical Engineering and technology. 2018; 9(9): 1212 - 1218.

[12] Adejobi OS, Akingbemisola P. Comparative analysis of noise pollution levels on selected landuse areas in Lagos State, Nigeria. Ethiopian Journal of Environmental Studies and Management. 2019; 13(3): 272 - 286.

[13] Oluwaseun 00, Michael UO, Oladayo EO. Study of road traffic noise pollution and impacts on residents of Ikeja Local Government area of Lagos State, Nigeria. International Journal of Scientific and Engineering Research. 2015; 6(5): 1108 - 1117.

[14] Oludele MS, Olumuyiwa A0, Nurudeen A. The dimensions of environmental pollution in Lagos metropolis, Nigeria. Journal of Sustainable Development in Africa. 2015; 17(3): 96 - 114.

[15] Amir EF. A mathematical model of noise pollution in streets of Tehran near IKIA airport. Environmental Impact of Aviation and Sustainable Solution. 2019; 1 - 10.

[16] Wojuade CA, Olateju AP. Assessment of traffic noise pollution in residential neighbourhood of Lagos, Nigeria. International Journal of Research and Review. 2020; 7(9): 396 - 403. 
[17] Echonews Lagos Community Edition. Oshodi - Isolo Local Government in retrospect. Accessed date: 25 November 2021.

[18] DB city.com. Geographical information of Oshodi - Isolo. Accessed date: 23 November 2021.

[19] Abstract of Local Government statistics. Ministry of Economic planning and Budget, Alausa, Ikeja, Lagos. 2017.

[20] Oshodi - Isolo Local Government manpower.com.hg. Accessed date: 24 November 2021.

[21] City Population. Map of Oshodi/Isolo Local Government of Lagos State. 2016.

[22] Lagos State Environmental Protection Agency (LASEPA). Guidelines on noise pollution. Accessed date: 27 November 2021.

[23] National Environmental Standards and Regulation Enforcement Agency (NESREA). Noise standards and control regulation, Federal Republic of Nigeria official gazette. 2009; 17 - 22. 